\title{
Gijsbert Hoogendoorn
}

\section{Last Chance Tourism in South Africa: Future Research Potential?}

\section{Abstract}

Last Chance Tourism (LCT) is defined by tourists' urgent visits to landscapes and seascapes, natural environments and places of social and cultural importance/heritage before they disappear. The obliteration of these environments is attributed to the rapid and destructive effects of global environmental change and globalization. These influences are leading to the demise of natural systems and biodiversity, including in polar regions and coral reef systems. Furthermore, cultures and traditions are also being lost. Scholarly investigations to date have reflected on the contention between the experiential gain in visiting destinations before they disappear on the one hand, and the losses to, and demise of, those very destinations through such visits. Despite aboveglobal-average rise in temperature, increasingly frequent droughts and flooding, as well as rapid globalization, the South African experience on LCT destinations remains under-investigated. This paper uses secondary sources to explore current and future destinations where cultural groups are threatened, fauna and flora are on the brink of extinction, and landscapes are changing for the worse. Future research opportunities are identified and conceptual concerns are discussed.

Keywords: last chance tourism, research opportunities, tourists, South Africa

\section{Introduction}

Climate change, global warming and extreme rates of species decline have led human-induced global environmental change to dramatically alter earth's biota to the point of no return (De Vos et al., 2015). Indeed, the scientific community is increasingly reaching consensus that earth's animal and plant life is entering a period known as the 'sixth mass extinction' (Ceballos et al., 2015). Simultaneously, the process of economic and socio-cultural globalization has had a myriad of effects, both positive and negative (Pieterse, 2020). Some have argued that there have been primarily unwanted consequences such as the death of languages, cultures and traditions (May, 2012). With this dramatic change to Earth's biota and rapid metamorphosis of society, tourists have awakened to this reality and its implications; they are therefore frantically travelling to view some of the planet's natural and cultural wonders before they disappear (Hall \& Saarinen, 2010; Lemelin et al., 2012). This type of tourism has been labelled 'Last Chance Tourism" (LCT), and has been defined as a phenomenon where 'tourists explicitly seek vanishing landscapes or seascapes, and/or disappearing natural and/or social heritage' (Lemelin et al., 2010, p. 478).

In terms of current research discourse on LCT, the dire impact of global environmental change has taken precedence over the disappearance of cultures, languages and traditions. This is arguably understandable given impending mass extinction but leaves an uneven contour of debate. In addition, the vast majority of studies have focused on countries in the Global North, especially in polar regions, and debates around LCT in the African context have remained largely unexamined. Exceptions are the limited analyses carried out on the pending disappearance of the snow-capping on Mount Kilimanjaro, mountain gorilla tourism in the Democratic Republic of the Congo and the apparent disappearance of the Victoria Falls in Zimbabwe (see Dube \& Nhamo, 2020; Frew, 2012; Newsome \& Rodger, 2012; Preston-Whyte $\&$ Watson, 2005). Studies

Gijsbert Hoogendoorn, PhD, Corresponding author, Associate professor, Department of Geography, Environmental Management and Energy Studies, University of Johannesburg, South Africa; ORCID ID: https://orcid.org/0000-0001-7969-7952; e-mail: ghoogendoorn@uj.ac.za

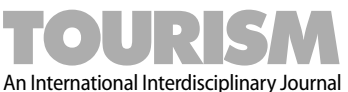


on LCT in the South African context remain mute; this is despite the economic benefits that could be gained from enhancing South Africa's LCT assets, products and destinations while maintaining their protection as far as possible with appropriate levels of supply and demand (Hoogendoorn \& Fitchett, 2018). The purpose of this paper is therefore to provide a research agenda for LCT destinations in South Africa in terms of implications, research opportunities, conceptual concerns, local economic potential and conservation possibilities. A subsidiary purpose of this paper is to stimulate debate around LCT in the southern African context. This paper uses carefully-selected secondary sources from peer-reviewed academic journals using keywords in Google Scholar and reputable national and international newspapers that actively avoids the proliferation of unverified claims (Rampersad \& Althiyabi, 2020), to develop the key points of the research.

The review and analysis undertaken is structured into three parts. First, a conceptual overview of the current debates in LCT tourism is provided in terms of benefits and pitfalls. Second, some of South Africa's LCT destinations are identified and key observations are made in terms of sustainable tourism development opportunities and potential disappearance of destinations. Finally, research opportunities are identified in South Africa and in southern Africa at large. The paper concludes with the key points identified through the investigation and suggests new research-paths going forward.

\section{Current debates on last chance tourism}

LCT as a topic of investigation has seen numerous publications since the early 2010s, culminating in an edited collection by Lemelin et al. (2012). Entitled "Last chance tourism: adapting tourism opportunities in a changing world", the volume spanned a wide variety of topics and geographical locations. In addition, diverse topics have been examined such as Antarctic cruise tourism (Eijgelaar et al., 2010), polar bear viewing (Dawson et al., 2010), disappearance of the Great Barrier Reef (Piggot-McKellar \& McNamara, 2017), glacier tourism (Stewart et al., 2016) and birding (Hvenegaard, 2012). Some of the key points that have emerged from research are explored in this literature review.

Eijgelaar et al. (2010) argue that LCT is an inherently problematic type of tourism. For example, by travelling to LCT destinations that are threatened by climate change, tourists are inevitably exacerbating consequences by contributing to the already excessive greenhouse gas levels. This in turn raises questions about tourists' responsibility, individual values and personal motivations while visiting destinations. Motivations to travel to LCT destinations are, unfortunately, in many cases driven by self-interest rather than behaviour that inhibits damage (Hindley \& Font, 2018). This self-interest leads many tourists to consider themselves as 'connoisseurs of a gone place' (Zerva, 2018, p. 1). This in turn gives tourists a certain reputation as 'explorers' or 'viewers' of authentic places before these sites disappear, thereby 'loving destinations to death' (Dawson et al., 2011). This view has gained support, with the notion of 'being an explorer' implying that the inherent nature of LCT is ethically problematic, especially in terms of the ways in which LCT destinations are marketed and managed.

In the typical fashion of neo-liberal systems of capital accumulation, the tourism industry in many cases tries to maximize visitor numbers and grow business opportunities before the destinations vanish (Stewart et al., 2016). Attempts to grow tourist numbers and maximize profits display levels of naivety and ignorance by the tourism industry, especially in terms of what their own contribution to the disappearance of destinations could be (Dawson et al., 2010). The level of disregard for environmental impacts is in many cases reinforced by the inherent human need to interact with (unspoiled) nature (Curtin, 2005). Both positive and negative tourist interaction with nature informs tourist identity; this is especially the case where LCT destinations are within tourists' own countries and contribute to feelings of patriotism or nationalism (Groulx et al., 2016). Indeed, the tourism industry as a whole has normalized travel to threatened or vulnerable destinations (Groulx et al., 2019). Yet Vila et al. (2016) have argued that promotion and advancing of place stewardship or ambassadorship for LCT destinations could offer potential gains that protect delicate ecosystems and landforms. For

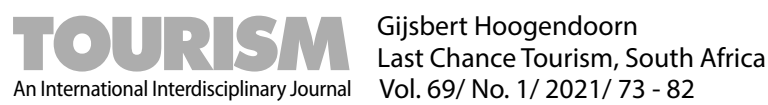


example, Piggot-McKellar and McNamara (2017) argue that, paradoxically, tourists often have higher levels of concern and care for declining environments, in some cases more so than local residents. A key concern in LCT research is the often-silent voice of host communities and their perceptions of LCT destinations (Schweinsberg et al., 2020).

Schweinsberg et al. (2020) have also argued that studies on LCT destinations are theoretically weak. To address the issues of theoretical rigor, LCT as a theme of investigation can also expand and overlap with other types of tourism investigations such as overtourism, dark tourism, doom tourism, catastrophe tourism, extinction tourism, heritage tourism and anthro-tourism as examples (Garland \& Gordon, 1999; Lemelin et al., 2010; Stewart et al., 2016). For example, the processes related to overtourism (Cheer et al., 2019) which is defined by the UNWTO as 'the impact of tourism on a destination, or parts thereof, that excessively influences perceived quality of life of citizens andlor quality of visitors' experiences in a negative way' (Koen et al., 2018, p. 3), are hastening the decline of LCT destinations like Mont Blanc in the French Alps and could be studied to establish the link between the two phenomena (LCT and overtourism) more directly. Thus, the French government has recently made concerted efforts to limit tourism numbers and unwanted actions at this destination (Crespo, 2020). The cultural and social aspects of LCT are severely under-researched in comparison to destinations that are impacted by global environmental change. One of the few examples is the recent research undertaken by Finastiian et al. (2019) that has investigated an interactive textile museum in Iran that is attempting to protect and preserve traditional and indigenous weaving methods and handicrafts. More studies like this are needed to contribute to the maturation of LCT research, especially as arts and crafts of indigenous nations across the globe are under threat from cultural, social, economic and political globalization. In some cases, LCT research does not just lack theoretical rigor but destinations are sometimes also incorrectly defined as 'last chance'. One such example is the Victoria Falls in Zimbabwe (see Dube \& Nhamo, 2020). Under current predictions it is unlikely that the Zambezi River will run dry as considerable inter-annual variability in flow is common despite significant water sources feeding the river (Moore et al., 2007; Ndlovu, 2019). Therefore, dramatic flow variability could be misinterpreted by researchers to be the result of climate change, and consequently the Victoria Falls have been incorrectly defined as an LCT destination. A key observation here is that incorrectly labeling of a destination as LCT can be problematic in that this branding is often utilized as a short-term marketing strategy to gain financial benefit before a destination disappears. This in turn could hurt the long-term sustainability of a destination.

On a positive note, while LCT is generally seen as a negative phenomenon despite minor gains of ambassadorship or stewardship, one process that could counteract LCT is the potential of 'de-extinction'. Here extinct species could be brought back to life, creating opportunities for 'first chance' tourism which is some case would lead LCT to be seen as a contradiction in terms (Whittle et al., 2015, p. 2).

\section{Development opportunities for last chance tourism destinations in South Africa}

South Africa is rich in natural and cultural tourism assets, making it one of the most-visited tourist destinations in Africa with 15825296 tourist arrivals in 2019 (StatsSA, 2019; Visser \& Hoogendoorn, 2011). Four and a half percent of the total South African workforce are employed in the tourism sector which is key in creating new job opportunities in a country with an unemployment rate of $26.7 \%$ (StatsSA, 2017). Because of the dire economic situation in the country, the need for job creation opportunities is critical for future growth trajectories and LCT could be one of these opportunities (Fitchett et al., 2016). Because some of South Africa's destinations are under threat due to global environmental change and globalization; the purpose of the following section is to explore potential research opportunities on tourism development in LCT destinations in South Africa.

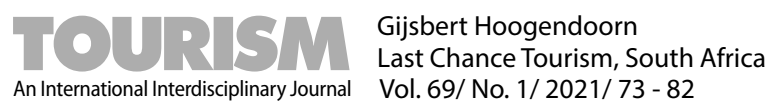




\subsection{Last chance cultural tourism}

The genocidal military campaigns and disease during various colonial periods in South Africa from 1652 to 1994 led to the almost complete elimination of South Africa's original inhabitants (Adhakari, 2010). The cultural groups that make up the Khoi-Khoi and San, also known collectively as the 'Bushmen', were particularly hard-hit by these campaigns, leading to almost complete societal, cultural and linguistic collapse. In the $21^{\text {st }}$ century the Bushmen culture is still under threat and seemingly disappearing, both from the uneven consequences of the market economy, and ill-conceived political policy (Suzman, 2017). Therefore tourism experiences related to Bushmen can be seen and interpreted as a form of 'last chance cultural tourism'. Owing to popular cinema portrayals in South Africa and abroad, such as 'The Gods Must Be Crazy' and 'A Far off Place', tourism products of the Bushmen are probably South Africa's most well-known anthropological or cultural tourism asset of so-called 'authentic cultures' or 'first nations' (Hüncke $\&$ Koot, 2012). The Bushmen brand as named by Koot (2018) is often a display of dance, music, food and language of a supposed 'authentic' but disappearing hunter-gatherer society. However, Koot (2016) skillfully challenged the perceived authenticity of these tourism products as a 'show' for tourists with the intent of 'performing the primitive' for economic survival (Robins, 2001). Consequently, the tourism industry portrays the Bushmen in particular ways, especially as a disappearing culture, and is marketed as such to Western tourists, but the tourism industry has been economically beneficial to several Bushmen (Hitchcock, 1997). Given that the geographical locations where Bushmen are primarily located have limited economic opportunities, tourism may be the Bushmen's 'last chance' for economic survival (Koot, 2013).

Given this background, novel LCT development trajectories can potentially offer a number of opportunities to the Bushmen for developing tourism enterprises. For example, South Africa has 34 languages of which only 11 are recognized as official languages (Head, 2019), and all of the unrecognized languages are those used by Bushmen. The languages that do not have official status are under threat, especially the Bushmen languages which have comparatively few mother-tongue speakers. Over the past 30 years, South Africa has already seen the death of four languages with a further two at present being particularly vulnerable. The N|u language has only three elderly speakers and Xiri around 87 speakers. In future, the smaller Bantu languages that do not have official status could also disappear (Seeth, 2019). Therefore, developing innovative ways within the tourism industry/economy for preserving these languages such as language museums and tours, will not only be valuable in terms of protecting South African indigenous cultures as such, but could also bring income to desperately under-resourced and economically lagging parts of South Africa. Indeed, along with the elderly populations being the last to be able to speak South Africa's original indigenous languages, the ethnobotanical knowledge of the Bushmen cultures is also disappearing. Guided tours could be developed to take tourists on ethnobotanical tours which would bring in additional income, but also preserve this rapidly disappearing knowledge (Van Wyk, 2015). Measures for protecting the knowledge from biopiracy would need to be investigated and put in place (Abu \& Webb, 2017).

Bushmen rock art has also been threatened and destroyed by tourists and residents in areas with exquisite paintings. In an attempt to address this unfortunate situation, Duval and Smith (2013) have conducted a comprehensive survey of the challenges facing the protection, preservation and safety of rock art in the uKhahlamba/Drakensberg World Heritage Site in the Kwazulu-Natal province, which has experienced tragic losses in rock art. Duval and Smith (2013) argue that rock art tourism is not promoted and sustained sufficiently by different stakeholders to preserve the art. Therefore, if the issue of sustainability of tourism and rock art is not addressed effectively, it could soon be seen as an example of LCT; this is over and above the rock art that has already disappeared owing to human interference.

While there are more examples of cultures in South Africa that are under threat, the Bushmen are probably the most threatened and therefore arguably require the most attention from an LCT perspective.

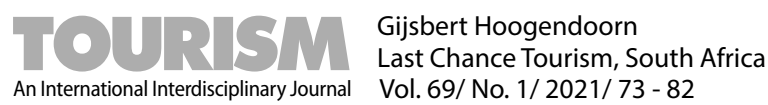




\subsection{Decline in biodiversity and possible last chance tourism opportunities}

South Africa hosts iconic nature-based tourism assets known for its rich biodiversity (Spenceley, 2005; Hoogendoorn \& Rogerson, 2015, 2016). Therefore, southern African countries have struck agreements to enhance the region's biodiversity by establishing a variety of transfrontier parks, to allow greater possibility of natural migration patterns of animals to be reestablished (Ferreira, 2014; Ferreira \& Harmse, 1999; Hoogendoorn et al., 2019). Despite the good intentions of advancing the biodiversity in these parks, wildlife has been threatened by a variety of issues of which poaching is the most publicized example (Lubbe et al., 2019). The poaching of white and black rhinos in the Kruger National Park and other national parks in the country is of particular concern (Hübschle, 2017). For example, South Africa has in the region of 19700 rhinos which make up $84 \%$ of the white rhino population globally (Crookes, 2017). There is still significant concern that South Africa's national parks may witness the extinction of the rhino in the wild, given challenges faced by anti-poaching campaigns (Ferreira et al., 2014). Despite this difficult situation, the rapid decline in rhino numbers has enhanced their appeal; this is especially true in the Kruger National Park as the last stronghold of rhino populations. As Morais et al. (2018, p. 446) have stated: 'Ironically, in fact, it can be argued that rhino poaching is exponentially increasing the economic value of the rhino viewing experience'. Although not labelled as such by nature reserves in southern Africa, rhino viewing is very much an example of LCT, unless proactive measures can be put in place to ensure the survival of the rhino. This is despite the paradox of financial gain because of the last chance viewing opportunities.

In spite of the desperate situation faced in conserving the rhino, it could be argued that the fauna and flora that does not fall within the label of 'charismatic' are facing similar threats without widespread awareness (see Monsarrat \& Kerley, 2018, for definitions of charismatic fauna). Herein lies the opportunity to enhance touristic opportunities by means of the following avenues. For example, according to Mueni (2019), South Africa in particular hosts a variety of animal species that could go extinct in the near future. In many cases the endangered animals form a crucial part of the tourism products of national and private game reserves. There are, however, other important examples of threatened species, other than the white and black rhino, such as the cheetah, African wild dog, African penguin, blue crane, Cape vulture and the bearded vulture. There are also lesser-known examples, such as the riverine rabbit, several species of golden mole, oribi, Temminck's pangolin, Pickergill's reedfrog, southern banded black snake eagle, Albany adder, the Knysna seahorse, and bird species such as the South African bald ibis, Cape gannet, African black oystercatcher, and the Damara tern (Mueni, 2019). Tourism opportunities could be developed around these less famous examples as a marketing strategy to view these animals with the intention of conducting fund-raising for conservation before these species ultimately disappear. Given that game reserves where many of these endangered animals are found, already have significant tourist visitation numbers tourists' interests could be coaxed towards viewing these species rather than focusing solely on the famous 'Big Five' and thus further enhancing the appeal of the nature reserves.

Marine invertebrates, while not a key tourism product in South Africa, are also under threat and could disappear because of overharvesting of populations and eutrophication of the ocean caused by climate change (Fitchett et al., 2019). Eutrophication jeopardizes the sustainable harvesting of langoustines, haliotis, crayfish and prawns for seafood festivals along the coast of South Africa and seafood restaurants more generally, which in turn threatens the culinary tourism products of the country (Bhoola \& Sing, 2018).

\subsection{Future climate change and last chance tourism}

The fifth assessment report of the Intergovernmental Panel on Climate Change (IPCC) entitled "Global warming of $1.5^{\circ} \mathrm{C}$ " paints a fairly dire picture for LCT destinations globally (Hoogendoorn \& Fitchett, 2020). To highlight specific cases of LCT destinations in South Africa, the following examples may be considered.

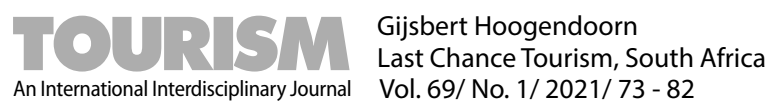


First, many South African beaches on the eastern and southern coasts of the country may experience flooding because of sea level rise (Fitchett et al., 2016). This will invariably result in certain beaches not being viable as tourist destinations and this will consequently have negative economic effects on coastal towns that rely on second home tourism for economic survival (Friedrich et al., 2020a; Friedrich et al., 2020b; Hoogendoorn $\&$ Visser, 2015). Second, ocean warming may eliminate the annual sardine run and the tourism industry supported by this natural phenomenon (Fitchett et al., 2019). Third, increases in droughts and elevated temperatures could put nature reserves into dire situations where large mammals may perish and thus proverbially 'killing' the main attraction of the reserves (Smith \& Fitchett, 2020). Nature reserves could become economically unviable and therefore shut down as tourism destinations. Indeed, droughts and heat could also potentially severely harm both the wine tourism industry and botanical tours in the Western Cape province (Hoogendoorn \& Fitchett, 2020).

Saarinen et al.(2012) note that owing to increasing drought and aridification, desert tourism experiences could be enhanced, essentially as first chance tourism; however, this process is evolving and it may also mean that semi-arid or non-desert locations are due to disappear and become LCT destinations. Recent examples of massive and extreme fires events in Australia have brought the viability of tourism into question in many locales (Hennessy, 2020). While not nearly at the same scale and extent, the destructive nature of the fires in the south-western and southern Cape such as the one in Knysna during 2017 (Kraaij et al., 2018) poses a threat to the tourism economy of the region. Under worsening circumstances of climate change, predominantly 'tourism towns' like Knysna may become a LCT destination if appropriate fire management measures are not implemented. Ultimately, the best way to avoid any of these cases becoming LCT destinations is to implement mitigating practices (Peeters \& Eijgelaar, 2014).

\section{What are the future research opportunities?}

The examples mentioned in this paper could all potentially serve as future case studies for both global environmental change and 'disappearing' cultures owing to globalization. Ethnographic studies gauging the views of Bushmen on being viewed as going 'extinct' or being subjects of LCT could be considered. Moreover, tourists who take part in indigenous tourism could also be studied to gauge their motivations for engaging in this type of tourism, and following their trip, their perceptions of this tourism experience. Other threatened indigenous groups in southern Africa such as the Ovahimba in Namibia have already been studied (Saarinen, 2011), although not from an LCT perspective; these types of studies could be expanded to a variety of groups within South Africa.

Local Economic Development (LED) has seen plenty of research in South Africa (Rogerson \& Nel, 2016), but the interplay between LED and last chance tourism has not been investigated as yet. In addition, LED as a policy could be investigated and implemented through participatory action research methods. This would aid the development of tourism entrepreneurial opportunities that may benefit communities, at least in the short term, and potentially contribute to development outcomes and processes that could bring cultures, languages and traditions back from the brink of extinction. An example of this could be the implementation of participatory action research projects like People-First Tourism (www.peoplefirsttourism.com), where Bushmen could be assisted in managing their own market access through frugal information technologies (Hoogendoorn, 2017; Morais et al., 2016). In terms of biodiversity and global environmental change, multiple cross- and sub-disciplinary studies can be conducted to investigate the different options such as LCT and how this relates to drought, fire, poaching, flooding, biodiversity loss and desertification. It would also be important that research identifies the potential benefits and pitfalls of developing LCT destinations in terms of where LCT could bring back destinations and products from extinctions. There also needs to be investigation of the ways in which, but also where LCT could hasten the demise of destinations. 


\section{Conclusion}

The purpose of this paper was to investigate LCT as a potential avenue of investigation within South Africa. This was achieved by way of an analysis of the main international discourses focused on this area of investigation. Thereafter followed an application of the LCT concept to cultural tourism, loss of biodiversity and climate change in the South African context. Finally, a few potential avenues of future investigatory paths were outlined.

LCT is ultimately both a blessing and a curse and is invariably a short-term marketing strategy and could be considered a poor investment choice in the long term. Despite LCT being a self-fulfilling prophecy, it is possible that if implemented in a considered way, it could nevertheless be utilized for the betterment of economic conditions and natural environments. Yet, at the same time, tourists could harm the fragile cultural, natural and social environments they engage which undermines its future survival. The tourism industry globally is not for the most part known for being environmentally responsible and tourists therefore continue to visit LCT destinations regardless. Therefore, research will engage in a 'circular debate' to persistently warn the tourism industry of its unwanted actions. One solution to this impasse is to dramatically shift the geographic gaze of LCT research away from Arctic and Antarctic regions towards the Global South where higher economic reliance on tourism industry could enhance responsible practices. The increased awareness could catalyze governments, tourists and other stakeholders to act before destinations are driven beyond the point of no return. Indeed, studies from the Global South could also bring perspectives into play not previously considered in this geographic context.

The implications of LCT for the South African tourism industry cannot be seen in isolation; many of the effects and impacts mentioned in this investigation, especially in terms of culture, biodiversity and the impacts of climate change, will also be experienced by other countries in southern Africa. Ideally, research into LCT could assist in creating awareness around species that could go extinct, and therefore provide much-needed funding for conservation and research to inhibit the decline of said species. LCT could also be particularly positive as a last-ditch effort to protect and preserve cultures, language and traditions, for example, through tourism micro-entrepreneurship that could give individuals and communities the impetus to protect their heritage, especially if there is an economic imperative to do so.

\section{Acknowledgements:}

Jennifer Fitchett, Stasja Koot and Gustav Visser are thanked for helpful comments on earlier drafts of this paper.

\section{References}

Abu Hanifah, N., \& Webb, A.B. (2017). Ecotourism and biopiracy: A legal perspective on the sustainability of tourism destination in Malaysia. In A. Saufi, I. Andilolo, N. Othman, \& A. Lew (Eds.), Balancing development and sustainability in tourism destinations (pp. 9-19). Springer.

Adhikari, M. (2010). A total extinction confidently hoped for: The destruction of Cape San society under Dutch colonial rule, 1700-1795. Journal of Genocide Research, 12(1-2), 19-44.

Bhoola, S., \& Sing, A. (2018). Seafood, its appreciation and capacity to contribute towards the South African tourism industry: A case study of Chinese tourists in Durban, Kwazulu-Natal. African Journal of Hospitality, Tourism and Leisure, 7(3), 1-14.

Ceballos, G., Ehrlich, P.R., Barnosky, A.D., Garcia, A., Pringle, R.M., \& Palmer, T.M. (2015). Accelerated modern human-induced specie losses: Entering the sixth mass extinction. Science Advances, 1(5), 1-5.

Cheer, J., Milano, C., \& Novelli, M. (2019). Tourism and community resilience in the Anthropocene: Accentuating temporal overtourism. Journal of Sustainable Tourism, 27(4), 554-572.

Crespo, G. (2020, February 14). France to limit access to Western Europe's highest mountain in conservation effort. CNN. https://edition.cnn.com/2020/02/13/world/macron-mont-blanc-climate-change-tourist-overcrowding/index.html

Crookes, D.J. (2017). Does a reduction in the price of rhino horn prevent poaching? Journal for Nature Conservation, $39,73-82$.

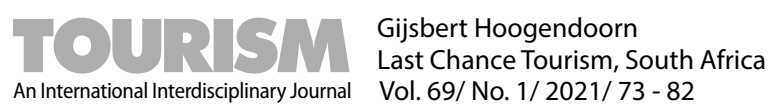


Curtin, S. (2005). Nature, wild animals and tourism: An experiential view. Journal of Ecotourism, 4(1), 1-15.

Dawson, J., Johnston, M.J., Stewart, E.J., Lemieux, C.J., Lemelin, R.H., Maher, P.T., \& Grimwood, B.S.R. (2011). Ethical considerations of last chance tourism. Journal of Ecotourism, 10(3), 250-265.

Dawson, J., Stewart, E.J., Lemelin, H., \& Scott, D. (2010). The carbon cost of polar bear viewing tourism in Churchill, Canada. Journal of Sustainable Tourism, 18(3), 319-336.

De Vos, J.M., Joppa, L.N., Gittleman, J.L., Stephen, P.R., \& Prim, S.L. (2015). Estimating the current normal background rate of species extinction. Conservation Biology, 29(2), 452-462.

Dube, K., \& Nhamo, G. (2020). Tourist perceptions and attitudes regarding the impact of climate change on Victoria Falls. Bulletin of Geography: Socio-Economic Series, 47, 27-44.

Duval, M., \& Smith, B. (2013). Rock art tourism in the uKhahlamba/Drakensberg World Heritage Site: Obstacles to the development of sustainable tourism. Journal of Sustainable Tourism, 21(1), 134-153.

Eijgelaar, E., Thaper, C., \& Peeters, P. (2010). Antarctic cruise tourism: Paradoxes of ambassadorship, "last chance tourism” and greenhouse gas emissions. Journal of Sustainable Tourism, 18(3), 337-354.

Ferreira, S.L.A. (2014). Kruger National Park: Tourism development and issues around the management of large numbers of tourists. Journal of Ecotourism, 13(1), 16-34.

Ferreira, S.L.A., \& Harmse, A.C. (1999). The social carrying capacity of the Kruger National Park, South Africa: Policy and practice. Tourism Geographies, 1(3), 325-342.

Ferreira, S.M., Pfab, M., \& Knight, M. (2014). Management strategies to curb rhino poaching: Alternative options using a cost-benefit approach. South African Journal of Science, 110(5-6), 1-8.

Finastiian, M., Farsani, N.T., \& Mortazavi, M. (2019). Traditional weaving house in Isfahan as a museum for promoting last-chance tourism. Museum Management and Curatorship, 34(4), 448-461.

Fitchett, J. M., Grab, S. W., \& Portwig, H. (2019). Advances in the timing of sardine migration in the South-West Indian Ocean: Ocean-atmospheric considerations under global change. South African Journal of Science, 115(7-8), 61-66.

Fitchett, J.M., Grant, B., \& Hoogendoorn, G. (2016). Climate change threats to two low-lying South African coastal towns. South African Journal of Science, 112(5/6), 1-9.

Fitchett, J.M., Hoogendoorn, G., \& Robinson, D. (2016). Data challenges in the calculation of Tourism Climate Index (TCI) scores in South Africa. Tourism: An International Interdisciplinary Journal, 64(4), 359-370.

Frew, E. (2012). Advertising world heritage sites: Tour operators and last chance destinations. In H. Lemelin, J. Dawson, \& E.J. Stewart (Eds.), Last chance tourism: Adapting tourism opportunities in a changing world (pp. 117-132). Routledge.

Friedrich, J., Stahl, J., Fitchett, J.M., \& Hoogendoorn, G. (2020a). To beach or not to beach? Socio-economic factors influencing beach tourists' perceptions of climate change and weather in South Africa. Transactions of the Royal Society of South Africa, 74(2), 194-202.

Friedrich, J., Stahl, J., Hoogendoorn, G., \& Fitchett, J.M. (2020b). Hazard-activity pairs exploring climate change threats to the South African beach tourism sector. Weather, Climate and Society, 12(3), 529-544.

Garland, E., \& Gordon, R.J. (1999). The authentic (in)authentic: Bushman anthro-tourism. Visual Anthropology, 12(2-3), 267-287.

Groulx, M., Boluk, K., Lemieux, C.J., \& Dawson, J. (2019). Place stewardship among last chance tourists. Annals of Tourism Research, 75, 202-212.

Groulx, M., Lemieux, C., Dawson, J., Stewart, E., \& Yudina, O. (2016). Motivations to engage in last chance tourism in the Churchill Wildlife Management Area and Wapusk National Park: The role of place identity and nature relatedness. Journal of Sustainable Tourism, 24(11), 1523-1540.

Hall, C.M., \& Saarinen, J. (2010). Last chance to see? Future issues for polar tourism and change. In C.M. Hall, \& J. Saarinen (Eds.), Tourism and change in polar regions: Climate environments and experiences (pp. 415-421). Routledge.

Head, T. (2019, February 14). Four South African languages - Including Afrikaans - "At risk of extinction". The South African. https://www.thesouthafrican.com/lifestyle/south-african-languages-extinction-afrikaans/

Hennessey, K. (2020, February 9). Tourism after bushfires: “The whole area is screaming for people to come back". The Guardian. https://www.theguardian.com/lifeandstyle/2020/feb/10/back-to-the-bush-three-recovering-nsw-regions-eager-for-visitors

Hindley, A., \& Font, X. (2018). Values and motivations in tourist perceptions of last-chance tourism. Tourism and Hospitality Research, 18(1), 3-14.

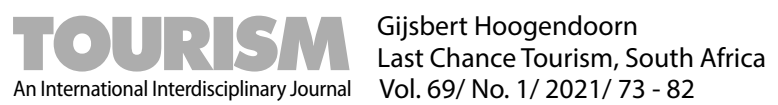


Hitchcock, R.K. (1997). Cultural, economic, and environmental impacts of tourism among Kalahari Bushmen.

In E. Chambers (Ed.), Tourism and culture: An applied perspective (pp. 93-128). State University of New York Press.

Hoogendoorn, G. (2017). Fly-fishing as ecotourism in South Africa: A case study. Journal of Ecotourism, 16(2), $152-168$.

Hoogendoorn, G., \& Fitchett, J.M. (2018). Tourism and climate change: A review of threats and adaptation strategies for Africa. Current Issues in Tourism, 21(7), 752-759.

Hoogendoorn, G., \& Fitchett, J.M. (2020). Fourteen years of tourism and climate change research in southern Africa: Lessons on sustainability under conditions of global change. In M. Stone, M. Lenao, \& N. Moswete (Eds.), Natural resources, tourism and community livelihoods in southern Africa: Challenges of sustainable development (pp. 78-89). Routledge.

Hoogendoorn, G., \& Rogerson, C.M. (2015). Tourism geography in the global South: New South African perspectives. South African Geographical Journal, 97(2), 101-110.

Hoogendoorn, G., \& Rogerson, C.M. (2016). New perspectives on Southern African tourism research. Tourism: An International Interdisciplinary Journal, 64(4), 355-357.

Hoogendoorn, G., \& Visser, G. (2015). Focussing on the 'blessing' and not the 'curse' of second homes: Notes from South Africa. Areas, 47(2), 179-184.

Hoogendoorn, G., Kelso, C., \& Sinthumule, I. (2019). Tourism in the Great Limpopo Transfrontier Park: A review. African Journal of Hospitality, Tourism and Leisure, 8(5), 1-15.

Hübschle, A.M. (2017). The social economy of rhino poaching: Of economic freedom fighters, professional hunters and marginalized local people. Current Sociology, 65(3), 427-47.

Hüncke, A., \& Koot, S. (2012). The presentation of Bushmen in cultural tourism: Tourists' images of Bushmen and the tourism providers' presentation of (Hai//om) Bushmen at Treesleeper Camp, Namibia. Critical Arts: South-North Cultural and Media Studies, 26(5), 671-689.

Hvenegaard, G.T. (2012). Last chance birding. In H. Lemelin, J. Dawson, \& E.J. Stewart (Eds.), Last chance tourism: Adapting tourism opportunities in a changing world (pp. 71-88). Routledge.

Koens, K., Postma, A., \& Papp, B. (2018). Is overtourism overused? Understanding the impact of tourism in the city context. Sustainability, 10, 4384, 1-15.

Koot, S. (2016). Contradictions of capitalism in the South African Kalahari: Indigenous Bushman, their brand and baasskap in tourism. Journal of Sustainable Tourism, 25(8-9), 1211-1226.

Koot, S. (2018). The Bushman brand in southern African tourism: An indigenous modernity in a neoliberal economy. Senri Ethnological Studies, 99, 231-250.

Koot, S. (2013). Dwelling in tourism: Power and myth amongst Bushmen in Southern Africa [Doctoral dissertation]. African Studies Centre, Leiden.

Kraaij, T., Baard, J.A., Arndt, J., Vhengani, L., \& van Wilgen, B.W. (2018). An assessment of climate, weather and fuel factors influencing a large, destructive wildfire in the Knysna region, South Africa. Fire Ecology, 14(4), 1-12.

Lemelin, H., Dawson, J., \& Stewart, E.J. (2012). Last chance tourism: Adapting tourism opportunities in a changing world. Routledge.

Lemelin, H., Dawson, J., Stewart, E.J. Maher, P., \& Lueck, M. (2010). Last-chance tourism: The boom, doom, and gloom of visiting vanishing destinations. Current Issues in Tourism, 13(5), 477-493.

Lemelin, H., Stewart, E.J., \& Dawson, J. (2012). An introduction to last chance tourism. In H. Lemelin, J. Dawson, \& E.J. Stewart (Eds.), Last chance tourism: Adapting tourism opportunities in a changing world (pp. 3-9). Routledge.

Lubbe, B.A, du Preez, E.A., Douglas, A., \& Fairer-Wessels, F. (2019). The impact of rhino poaching on tourist experiences and future visitation to National Parks in South Africa. Current Issues in Tourism, 22(1), 8-15.

May, S. (2012). Language and minority rights: Ethnicity, nationalism and the politics of language. Routledge.

Monsarrat, S., \& Kerley, G.I.H. (2018). Charismatic species of the past: Biases in reporting of large mammals in historical written sources. Biological Conservation, 223, 68-75.

Moore, A.E., Cotterill, F.P.D., Main, M.P.L., \& Williams, H.B. (2007). The Zambezi River. In A. Gupta (Ed.), Large rivers: Geomorphology and management (pp. 311-332). Wiley.

Morais, D.B., Bunn, D., Hoogendoorn, G., \& KC, B. (2018). The potential of tourism microentrepreneurship in the prevention of rhino poaching. International Development Planning Review, 40(4), 443-461.

Morais, D.B., Ferreira, B.S., Hoogendoorn, G., \& Wang, Y.A. (2016). Co-construction of knowledge through participatory action research: People-first tourism methodology and research focus. In Proceedings from the 47th Tourism and Travel Research Association Conference. Vail, CO, USA.

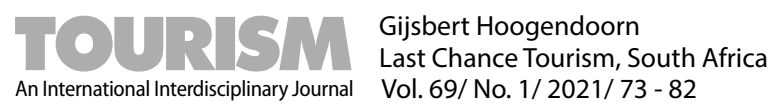


Mueni, P. (2019). Top 20 extinct and endangered species in South Africa with images. Briefly. https://briefly.co.za/34070-top-20-extinct-endangered-animals-south-africa-images.html

Ndlovu, P. (2019, December 11). Victoria falls not drying up. Chronicle. https://www.chronicle.co.zw/victoria-falls-not-drying-up/

Newsome, D., \& Rodger, K. (2012). Vanishing fauna of tourism interest. In H. Lemelin, J. Dawson, \& E.J. Stewart (Eds.), Last chance tourism: Adapting tourism opportunities in a changing world (pp. 56-70). Routledge.

Peeters, P.M., \& Eijgelaar, E. (2014). Tourism's climate mitigation dilemma: Flying between rich and poor countries. Tourism Management, 40, 15-26.

Pieterse, J.N. (2020). Globalization \& culture: Global mélange. Roman and Littlefield.

Piggot-McKellar, A.E., \& McNamara, K.E. (2017) Last chance tourism and the Great Barrier Reef. Journal of Sustainable Tourism, 25(3), 397-415.

Preston-Whyte, R.A., \& Watson, H.K. (2005). Nature tourism and climatic change in Southern Africa. In C.M. Hall \& J. Higham (Eds.), Tourism, recreation and climate change (pp. 130-142). Channelview.

Robins, S. (2001). NGO's, 'Bushmen' and double vision: The $p$ khomani San land claim and the cultural politics of 'community' and 'development' in the Kalahari. Journal of Southern African Studies, 27(4), 833-853.

Rogerson, C.M., \& Nel, E. (2016). Planning for local economic development in spaces of despair: Key trends in South Africa's 'distressed areas'. Local Economy, 31(1/2), 124-141.

Saarinen, J. (2011). Tourism development and local communities: The direct benefits of tourism to Ovahimba communities in the Kaokaland, Northwest Namibia. Tourism Review International, 15, 149-157.

Saarinen, J., Hambira, W. L., Atlhopheng, J., \& Manwa, H. (2012). Tourism industry reaction to climate change in Kgalagadi South District, Botswana. Development Southern Africa, 29(2), 273-285.

Schweinberg, S., Wearing, S., \& Lais, P. (2020). Host communities and last chance tourism. Tourism Geographies.

Seeth, A. (2019, February 2). The fight for indigenous language are important. Here's why. City Press. https://city-press.news24.com/News/the-fight-for-indigenous-languages-is-important-heres-why-20190221

Smith, T., \& Fitchett, J.M. (2020). Drought challenges for nature tourism in the Sabi Sands Game Reserve in the eastern region of South Africa. African Journal of Range \& Forage Science, 37(1), 107-117.

Spenceley, A. (2005). Nature-based tourism and environmental sustainability in South Africa. Journal of Sustainable Tourism, 3(2), 136-170.

StatsSA. (2017). Tourism jobs growth despite sluggish economy. Statistics South Africa. http://www.statssa.gov.za/?p=11800

StatsSA. (2019). Tourism (Report No. 03-51-02). Statistics South Africa.

Stewart, E.J., Wilson, J., Espiner, S., Purdie, H., Lemieux, C., \& Dawson, J. (2016). Implications of climate change for glacier tourism. Tourism Geographies, 18(4), 377-398.

Suzman, J. (2017). Affluence without abundance: The disappearing world of the Bushman. Bloomsbury.

Van Wyk, B.E. (2015). Die kulturele en praktiese waarde van inheemse kennis oor plantgebruike in die 21ste eeu [The cultural and practical value of indigenous knowledge before plant uses in the 21st century]. Suid-Afrikaanse Tydskrif vir Natuurwetenskap en Tegnologie, 34(1), 1-11.

Vila, M., Costa, G., Angulo-Preckler, C., Sarda, R., \& Avila, C. (2016). Contrasting views on Antarctic tourism: 'Last chance tourism' or 'ambassadorship' in the last of the wild. Journal Cleaner Production, 111(B), 451-469.

Visser, G., \& Hoogendoorn, G. (2011). Current paths in South African tourism research. Tourism Review International, 15(1-2), 5-20.

Whittle, P.M., Stewart, E.J., \& Fisher, D. (2015). Re-creation tourism: De-extinction and its implications for nature-based recreation. Current Issues in Tourism, 18(10), 908-912.

Zerva, K. (2017). “Chance tourism”: Lucky enough to have seen what you will never see. Tourist Studies, 18(2), $232-254$.

Submitted: April 11, 2020

Revised: May 29, 2020

Revised: July 29, 2020

Accepted: August 10, 2020

Refereed Anonymously

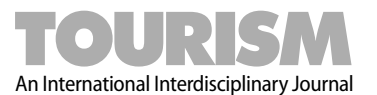

Gijsbert Hoogendoorn

Last Chance Tourism, South Africa

An International Interdisciplinary Journal Vol. 69/ No. 1/ 2021/ 73 - 82 